\title{
Ex vivo biomechanical testing of Funkquist B dorsal laminectomy between the sixth and seventh cervical vertebrae in dogs
}

\section{Julián Andres Sanjuan Galíndez ${ }^{1}$ (D) Bruno Watanabe Minto ${ }^{1^{*}}$ (D) Paulo Vinicius Tertuliano Marinho $^{2}$ (D) Adrielly Dissenha ${ }^{1}$ (D) Dayvid Vianeis Farias de Lucena ${ }^{1}$ (D) Vinicius dos Santos Vieira Dias ${ }^{3}$ (D) Luís Gustavo Gosuen Gonçalves Dias ${ }^{1}$ (D)}

${ }^{1}$ Faculdade de Ciências Agrárias e Veterinárias, Universidade Estadual Paulista (UNESP), Campus de Jaboticabal, 14884-900, Jaboticabal, SP, Brasil. E-mail: bruno.minto@unesp.br. *Corresponding author.

${ }^{2}$ Instituto Federal de Educação, Ciência e Tecnologia do Sul de Minas Gerais (IFSULDEMINAS), Campus Muzambinho, Muzambinho, MG, Brasil. ${ }^{3}$ Hospital, Escola Barão de Mauá, Ribeirão Preto, SP, Brasil.

\begin{abstract}
Dorsal laminectomy is routinely performed for spinal cord compressions or stenosis of the cervical vertebral canal. However despite good results, relevant complications have been described in dogs. Considering the incomplete understanding of the necessity for complementary surgical stabilization after performing laminectomies in the cervical region, this study compared the resistance and range of motion (ROM) of the cervical spinal column subjected to Funkquist B laminectomy between the sixth and seventh vertebrae in dogs. Forty-four cervical vertebral columns (C2-T1) of dogs, with an average weight of $26.2 \pm 3.8 \mathrm{~kg}$, were selected using radiography and computed tomography. Four experimental groups $(n=11)$ were established according to the mechanical test: two control groups (flexion and extension control) and two laminectomy groups (flexion and extension laminectomies). Numerical results of the maximum load for measuring the resistance and ROM of the columns of the two control groups and the two laminectomy groups were compared. The laminectomy groups showed a lower maximum load, regardless of the mechanical test performed $(P<0.001)$. The ROM was not influenced by laminectomy, the type of mechanical test (ventral flexion or extension), or its interaction $(P<0.05)$. There was no interaction between the effect of the laminectomy factors $(y e s$ or no) and the effect of the mechanical tests for ventral flexion or extension $(P<0.05)$. In conclusion, Funkquist $B$ dorsal cervical laminectomy between C6 and $C 7$ decreases mechanical resistance with a supraphysiological loading force but does not alter the ROM, suggesting that it can be used without additional mechanical stabilization in dogs.
\end{abstract}

Key words: biomechanics, dog, dorsal decompression, vertebral instability.

Análise biomecânica ex vivo dos efeitos da laminectomia dorsal Funkquist $B$ entre a sexta e a sétima vertebras cervicais em cães

RESUMO: A laminectomia dorsal é realizada com frequência no tratamento de compressões medulares ou estenose do canal vertebral cervical. No entanto, complicações relevantes têm sido descritas em cães. Considerando que ainda não há entendimento completo da necessidade de estabilização cirúrgica complementar após a realização de uma ou múltiplas laminectomias na região cervical, o objetivo deste estudo foi comparar a resistência e amplitude de movimento (ADM) da coluna cervical submetida à laminectomia Funkquist B entre a sexta e a sétima vértebras em cães. Quarenta e quatro colunas vertebrais cervicais (C2-T1) de cães, com peso médio de $26,2 \pm 3,8 \mathrm{~kg}$, foram selecionadas por meio de radiografia e tomografia computadorizada. Quatro grupos experimentais $(n=11)$ foram estabelecidos de acordo com o teste mecânico realizado: dois grupos controle (flexão e extensão controle) e dois grupos laminectomia (flexão e extensão laminectomia). Os resultados numéricos da carga máxima para medir a resistência e ADM das colunas dos dois grupos de controle e dos dois grupos de laminectomia foram comparados. Os grupos de laminectomia apresentaram menores valores de carga máxima, independentemente do teste mecânico realizado ( $P<0,001)$. A ADM não foi influenciada pela laminectomia, tipo de teste mecânico (flexão ou extensão ventral) ou sua interação $(P<0,05)$. Não houve interação entre o efeito do fator de laminectomia, sim ou não, ou o efeito do teste mecânico na flexão ou extensão ventral $(P<0,05)$. A laminectomia cervical dorsal Funkquist B entre C6 e C7 diminui a resistência mecânica com uma força de carga suprafisiológica, mas não altera a ADM, sugerindo que pode ser usada sem estabilização mecânica adicional em cães.

Palavras-chave: biomecânica, cão, descompressão dorsal, instabilidade vertebral.

\section{INTRODUCTION}

Spinal and spinal cord diseases can potentially cause permanent physical disability in small animals. Cervical spinal injuries yield alterations, such as hyperesthesia, motor dysfunction, and lameness due to nerve root compression, representing relevant proportions of cases in most veterinary reference centers (SANTINI et al., 2010; FUJIOKA et al., 2019).

Dorsal laminectomy was first mentioned more than five decades ago and is performed routinely for the treatment of syndromes that cause spinal cord compression or stenosis of the vertebral 
canal. Its application in the cervical region showed good clinical results (SHIMIZU et al., 2016). It is particularly used in compressive, single, or multiple conditions that affect the dorsal, lateral, and even ventral portions of the vertebral canal. Further, dorsal laminectomy has low morbidity, good prognosis, and excellent recovery in most cases (TAYLOR-BROWN et al., 2015; KOSUKE et al., 2016; HWANG et al., 2016; LEE et al., 2020).

Among the postoperative complications related to dorsal laminectomy, instability must be highlighted, especially because there is still no complete understanding of the need for complementary surgical stabilization in dogs after performing one or multiple laminectomies in the cervical region. Different experimental studies of the cervical spine in humans and simulations using the finite element method showed that laminectomy causes consistent biomechanical instability; hence, many cases require stabilization or the application of surgical techniques that do not cause significant instability to mitigate or prevent clinical changes (KUBO et al., 2003; SUBRAMANIAM et al., 2009; XIE et al., 2013; HEALY et al., 2016; LEWCHALERMWONG et al., 2018; TUAN et al., 2019; YOSHII et al., 2020; 10-16).

KOSUKE et al. (2016) reported the use of cervical laminectomy in two or more intervertebral spaces without stabilization in 90 small-breed dogs with intervertebral disc disease (up to $10 \mathrm{~kg}$ ). Approximately $100 \%$ of them started to walk between 1 and 20 days after surgery. Other authors report the use of different types of implants to stabilize the cervical spine after the use of laminectomy, as they believe that because it causes instability in humans, the same could happen in dogs (FERNANDES et al., 2019).

In addition, postoperative clinical worsening $(54 \%-70 \%)$ has been reported in dogs that underwent laminectomy or cervical hemilaminectomy. The reasons have not yet been elucidated; however, it may be related to spinal manipulation, spinal hypoperfusion, and/or postoperative instability (TAYLOR-BROWN et al., 2015; BÖSCH et al., 2017). In view of the need for a better understanding of the effects of laminectomy on postoperative stability of the cervical spinal columns, this study evaluated the effects of Funkquist $\mathrm{B}$ dorsal laminectomy on the stability of vertebral segments $\mathrm{C} 6$ and $\mathrm{C} 7$. We hypothesized that Funkquist B cervical laminectomy performed between C6 and C7 will not cause relevant biomechanical changes associated with instability in the cervical columns of large canine cadavers.

\section{MATERIALS AND METHODS}

\section{Preparation of specimens}

A total of 44 cervical columns (C2-T1) of male and female dogs aged between 2 and 10 years, weighing 20 to $30 \mathrm{~kg}$ (mean: $26.2 \mathrm{~kg}$ ), with similar dimensions, and without neuroanatomical or musculoskeletal changes were used.

All specimens were radiographed (Digital Radiography Equipment; Siemens RG150/100gl, Munich, Germany) in lateral and dorsoventral projections and subjected to computed tomography (GE HiSpeed FXI helical 4 channels) to identify any pre-existing changes. The vertebral columns of immature dogs (with opened growth plate), those with one or more apparent radiographic/tomographic changes, or those with altered bone density were not included in the study.

The bone surface of $\mathrm{C} 2$ and the vertebral body of $\mathrm{C} 7$ and $\mathrm{T} 1$ were treated via excision of the paravertebral soft tissue, while maintaining the epaxial musculature and preserving the spinal ligaments and articular capsules intact from the other vertebrae. To fix the C2-T1 specimens, we used 2-mm Steinmann pins and polymethyl methacrylate (PMMA). One pin was placed at the center of the vertebral body of $\mathrm{C} 7$ and another at the center of the body of T1, parallel to each other and perpendicular to the spinal canal using a low-speed drill (Stryker ${ }^{\circledR}$, System CD3), and cut using a shear leaving $10 \mathrm{~mm}$ of pin remaining on the sides.

PMMA, prepared from $80 \mathrm{~g}$ of polymer (powder) and $40 \mathrm{~mL}$ of monomer (liquid), was mixed in a stainless-steel vat and applied after aligning the column and placing the mold in $\mathrm{T} 1$ (without filling the spinous process) and in the vertebral body of $\mathrm{C} 7$ until complete polymerization. In the lateral region of the left transverse foramen and posterior to the right side of $\mathrm{C} 2$, a hole was created perpendicular to the spinal canal using a 5-mm stainless steel drill for subsequent placement of a Steinmann pin $(5 \mathrm{~mm})$ when placing a metallic device in the universal mechanical testing machine. The specimens were stored in towels moistened with sterile $0.9 \%$ saline solution; and subsequently, frozen and kept at a temperature of $-20^{\circ} \mathrm{C}$ until the day of the laminectomy and mechanical tests. During the biomechanical tests, the columns were kept moist.

\section{Experimental groups}

The columns were randomly distributed in four experimental groups $(\mathrm{n}=11)$ : ventral flexion control group (flexion control), untreated cervical 
columns for mechanical testing of ventral flexion; extension control group (extension control), untreated cervical spines for mechanical testing of extension; flexion laminectomy group (flexion laminectomy), laminectomy performed at the $\mathrm{C} 6-\mathrm{C} 7$ level for mechanical testing of ventral flexion; and extension laminectomy group (extension laminectomy), laminectomy performed at the $\mathrm{C} 6-\mathrm{C} 7$ level for mechanical testing of extension.

\section{Surgical techniques}

Funkquist B laminectomy between C6 and $\mathrm{C} 7$ was performed on the specimens. The spinous processes $\mathrm{C} 6-\mathrm{C} 7$ and approximately $66 \%$ of the length of the dorsal laminae of C6 and C7 were removed, maintaining the articular, caudal, and cranial facets intact (Figure 1).

\section{Biomechanical evaluation}

Two metallic devices were manufactured for positioning the cervical spine. The first metallic device with a cup at its base and a pulley close to its surface was positioned on the axial axis of the load cell of the universal mechanical testing machine without connection to it. A second metallic device made with AISI-304L stainless steel wire and shaped with a wing on one end and two wings on the other end was also used. For the assembly of the cervical spine, the caudal region (which contained the PMMA) was placed inside the metallic cup of the first metallic device, and three screws were inserted to threaded holes (evenly distributed in the circumference of the cup) present on the sides of the cup metal for fixing. In the cranial region of the cervical column, a 5-mm Steinmann pin was placed

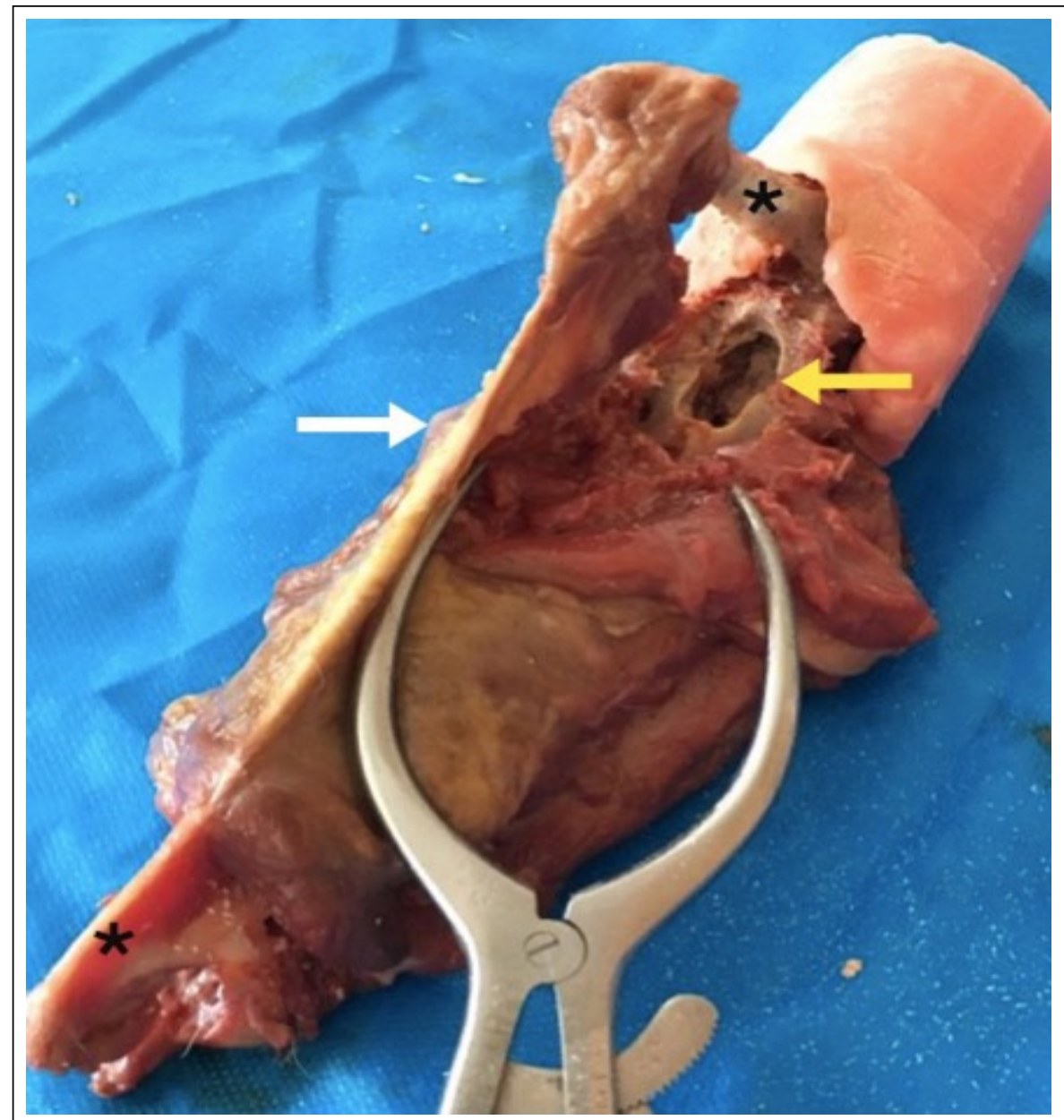

Figure 1 - Image showing laminectomy performed between C6 and C7 (yellow arrow). White arrow indicates the location of the nuchal ligament, which is fixed between $\mathrm{C} 2$ and T1 (asterisks). 
in the holes previously created in the transverse foramina of $\mathrm{C} 2$; subsequently, the two wings at the end of the second metallic device were placed on each lateral portion of the pin. After passing through the base of the pulley of the first metallic device, the other end of the thin metallic device was placed directly in another metallic device (cup with dowel that crossed the wing) connected to a load cell. The traction force applied by the load cell converted the movement of the cervical vertebral columns into flexion or extension according to their position in the cup of the first metallic device (Figure 2).

The mechanical tests of ventral flexion and extension were performed using the universal testing machine (UTM) EMIC ${ }^{\circledR}$, model DL10000 (São José dos Pinhais, PR), from the Bioengineering Laboratory of XXXXX (blinded). To perform the tests, we used a load cell with a capacity of $200 \mathrm{kgf}$, with a load application speed of $20 \mathrm{~mm} / \mathrm{min}$ and a pre-load of $20 \mathrm{~N}$. Each specimen was subjected to a complete cycle of ventral flexion or extension until failure. The TESC ${ }^{\circledR}$ program, coupled to the UTM, made the force curves in $\mathrm{N}$ versus ADM in $\mathrm{mm}$. The mechanical properties evaluated were the resistance and range of motion (ROM) of the cervical spine.

\section{Statistical analysis}

Data on the maximum load and ROM during ventral flexion and extension were analyzed in a completely randomized design and in a factorial arrangement $(\mathrm{A} \times \mathrm{B})$ : fixed effects of factor $\mathrm{A}$ (degrees of freedom [GL], GL 1) corresponding to the use of laminectomy, factor B corresponding to the mechanical test performed: extension or flexion (GL 1), and interaction between factors A and B (GL 1). The model included the random effects of the corpse (GL 10) and the errors corresponding to the model. These analyses of variance (ANOVA) were conducted using the Software R (version 3.5.1) with previous proof of the supposed mathematicians (Shapiro-Wilk test and Bartlett's test). Tukey's post-test was applied when ANOVA indicated a significant difference in the comparison of the means, and a $P$ value of $\leq 0.05$ was considered significant.

\section{RESULTS}

The laminectomy groups showed lower values of resistance (applying the same force in $\mathrm{N}$, regardless of the mechanical test performed) $(\mathrm{P}<0.001$; Table 1 and Figure 3$)$; the average value

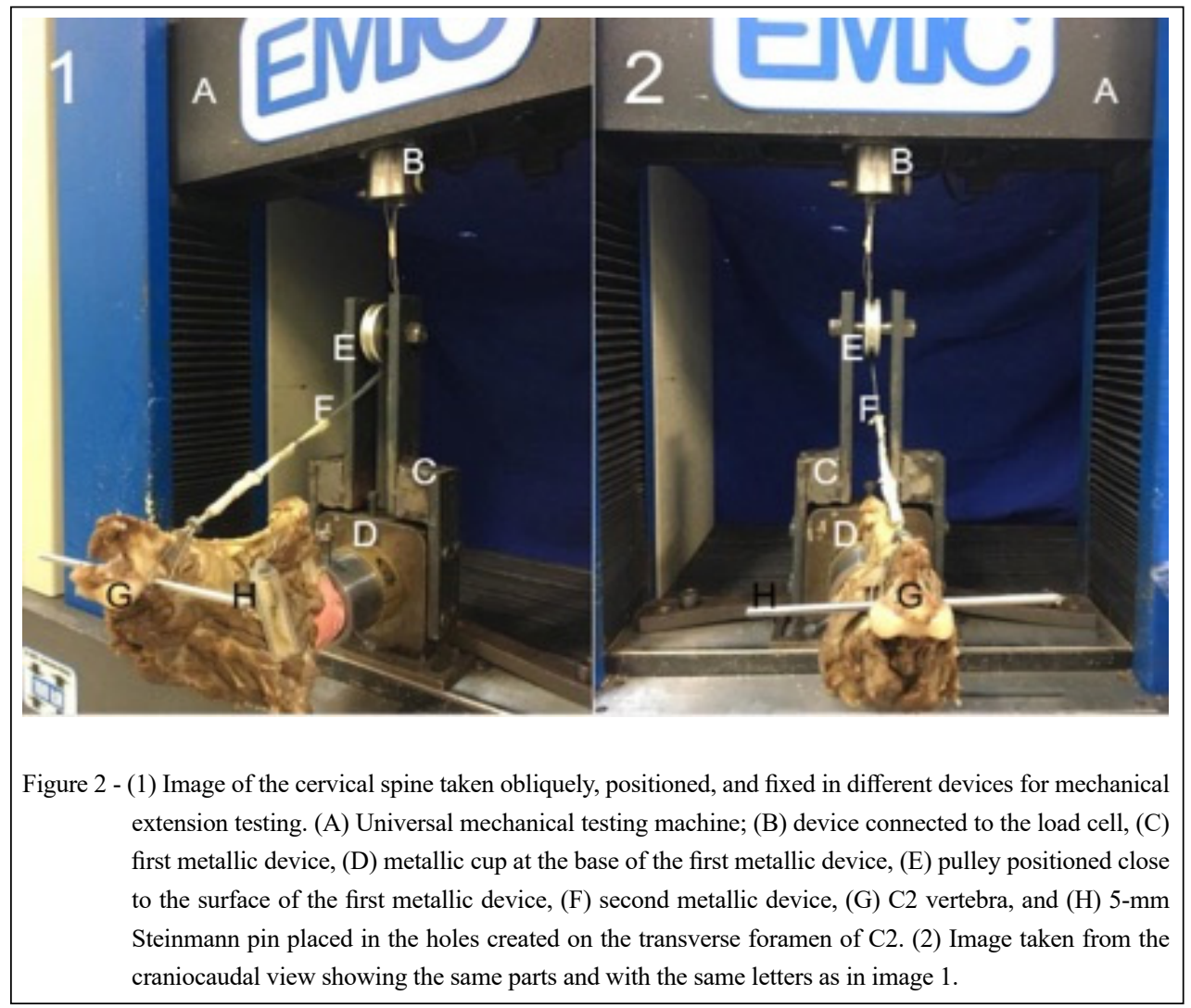

Ciência Rural, v.52, n.3, 2022. 
Table 1 - Maximum load and range of motion during the mechanical flexion and extension tests on the cervical spines with or without laminectomy.

\begin{tabular}{|c|c|c|c|c|c|c|c|}
\hline & \multicolumn{4}{|c|}{ 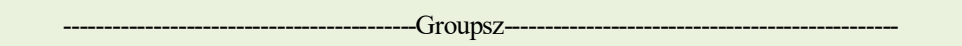 } & \multicolumn{3}{|c|}{-1-1-- } \\
\hline & Flexion control & Flexion laminectomy & Extension control & Extension laminectomy & ELMF & $\mathrm{EM}_{\mathrm{fe}}$ & ELMF vs $\mathrm{EM}_{\mathrm{fe}}$ \\
\hline $\operatorname{ML}(\mathrm{N})$ & $249.9 \pm 59.38$ & $118.67 \pm 29.16$ & $211.84 \pm 48.06$ & $131.69 \pm 46.35$ & $<0.001$ & 0.467 & 0.142 \\
\hline $\mathrm{ROM}(\mathrm{mm})$ & $94.80 \pm 19.91$ & $82.42 \pm 10.26$ & $83.62 \pm 13.27$ & $88.98 \pm 23.40$ & 0.599 & 0.729 & 0.188 \\
\hline
\end{tabular}

Data are presented as means \pm standard deviations.

Flexion control = control cervical columns for mechanical testing of ventral flexion, flexion laminectomy $=$ cervical columns with laminectomy at the $\mathrm{C} 6-\mathrm{C} 7$ level for mechanical testing of ventral flexion, extension control = control cervical columns for mechanical extension testing, extension laminectomy = cervical columns with laminectomy at the C6-C7 level for mechanical extension testing, $\mathrm{ELMF}=$ effect of the laminectomy factors (yes or no), $\mathrm{EM}_{\mathrm{fe}}=$ effect of the mechanical tests for ventral flexion or extension, $\mathrm{ROM}=$ range of motion.

of resistance for the cervical columns (C6-C7) that underwent laminectomy and the cervical spines that did not undergo laminectomy was $125.18 \mathrm{~N}$ and $230.76 \mathrm{~N}$, respectively.

There was no interaction between the effect of the laminectomy factors (yes or no) and between the effect of the mechanical tests for ventral flexion or extension for the evaluated variables $(\mathrm{P}>0.05)$ (Table 1). The ROM of the cervical vertebral segment was not influenced by the performance of laminectomy, the mechanical test, or its interaction $(\mathrm{P}>0.05)$, although numerically, the flexion control group presented higher values $(94.80 \pm 19.91 \mathrm{~mm}$ versus $82.42 \pm 10.26$ $\mathrm{mm})$. Deformation curves showing the ROM were also drawn for each group (Figure 4).

\section{DISCUSSION}

Based on the remarkable need for additional information on the mechanical effects of dorsal

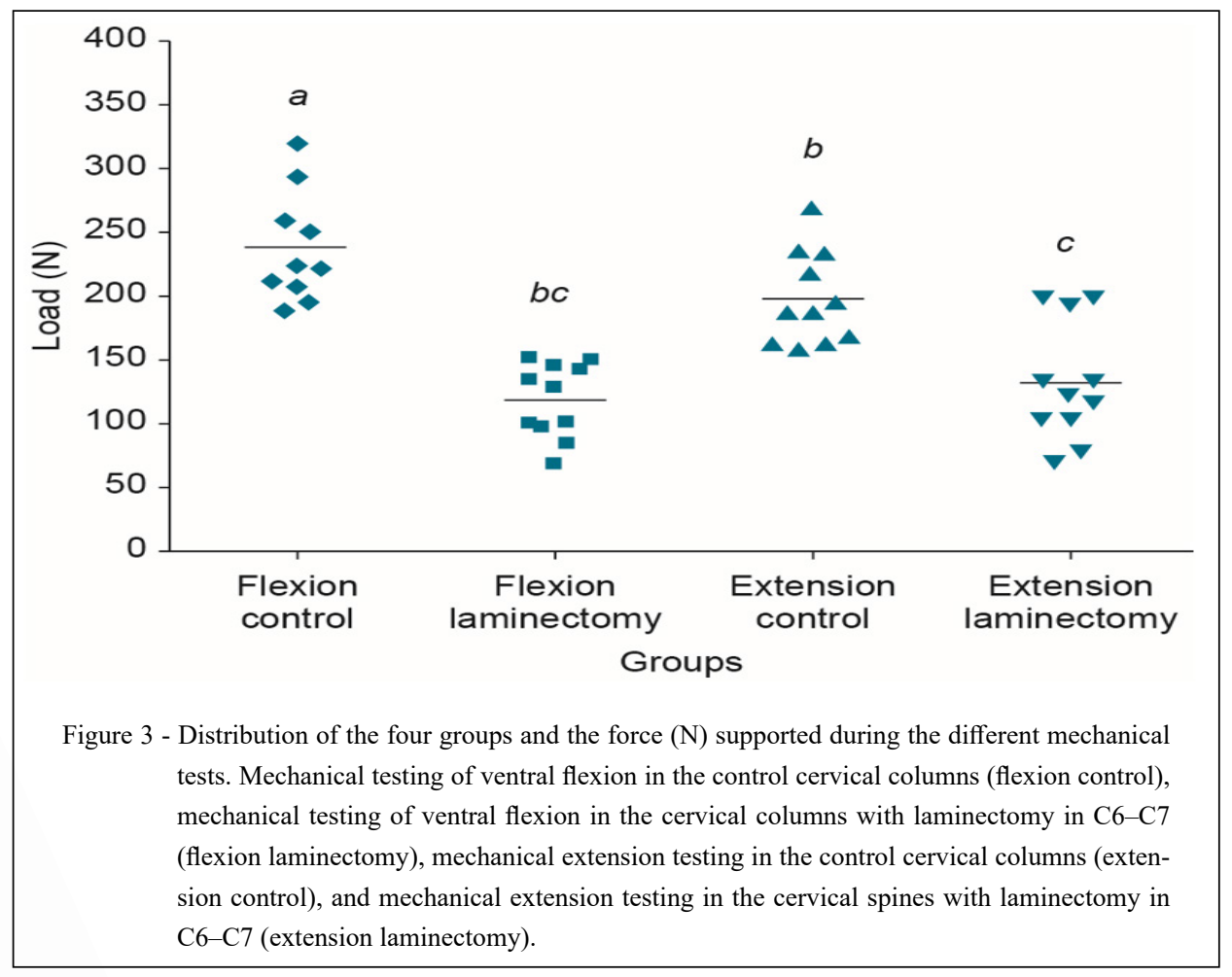

Ciência Rural, v.52, n.3, 2022. 


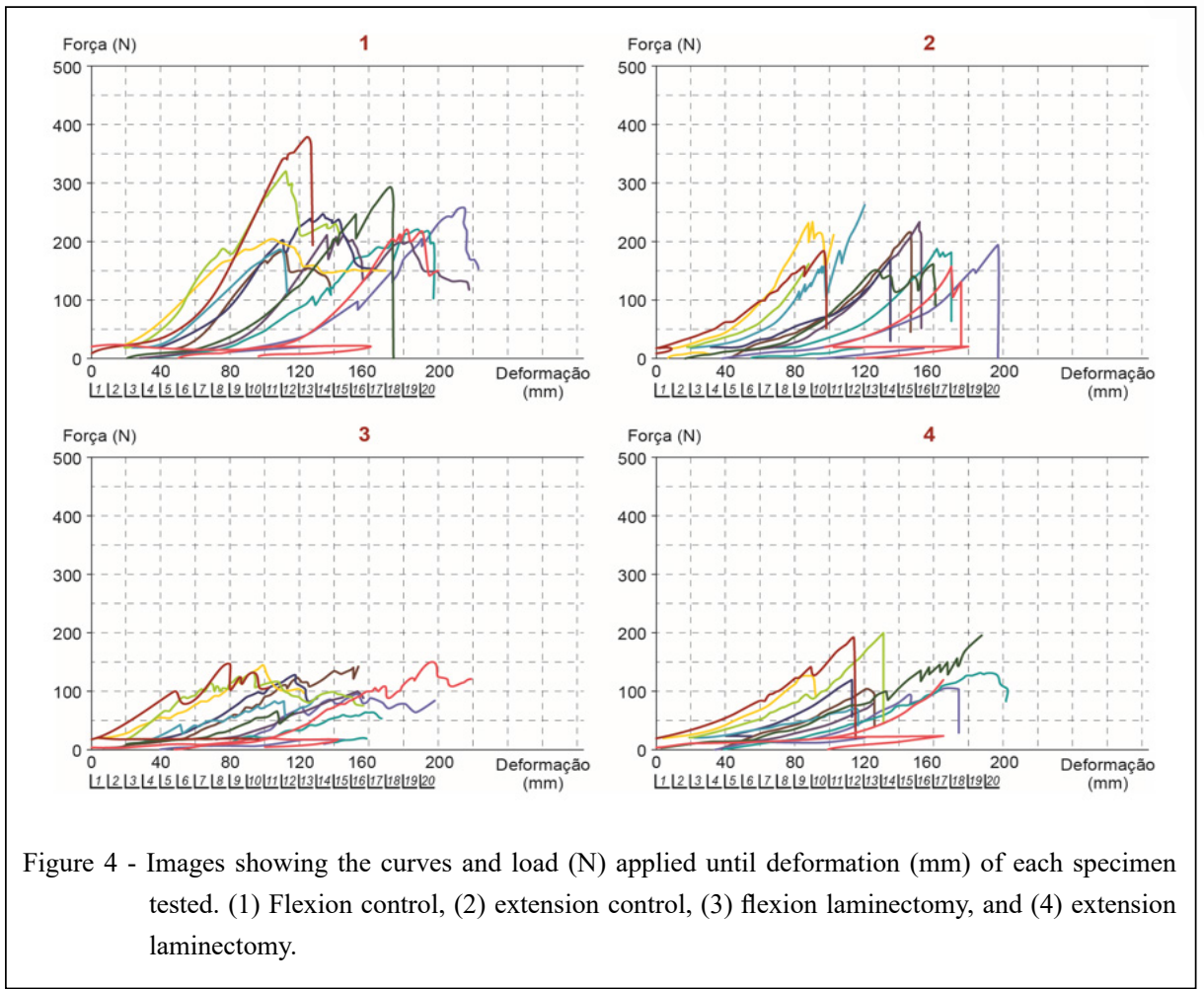

laminectomies on cervical spinal stability, this study investigated how Funkquist B laminectomy could change the movement pattern of the cervical spine in dogs. Our analysis showed that laminectomy had no significant influence on the ROM, validating the initial hypothesis. Moreover, the limited removal of the vertebral lamina and integrity of the interspinous ligaments, yellow ligament, and spinous processes between the $\mathrm{C} 6$ and $\mathrm{C} 7$ vertebrae might maintain the spatial integrity of the cervical spine.

Several vertebral and spinal cervical disorders require surgical decompression procedures and/or approach to the vertebral canal, such as ventral slot, dorsal laminectomy, hemilaminectomy, and distraction-fusion procedures or a combination of these (DA COSTA et al., 2008). Decompression techniques can reduce the stability of the functional vertebral unit (MACY et al., 1999; KOEHLER et al., 2005; ADAMO et al., 2007); this has been demonstrated in ventral access surgeries, such as disk fenestration and ventral slot (MOISSONNIER et al., 2014). On the contrary, only two studies have addressed the risk factors associated with cervical dorsal or dorsolateral decompression techniques in dogs (DE RISIO et al., 2002; TAYLOR-BROWN et al., 2015). In these studies, such techniques yielded a greater risk of neurological deterioration, with post-surgical instability being one of the suggested hypotheses, despite the absence of biomechanical studies.

The flexion and extension of the entire canine cervical spine mimic the cervical movements in vivo, and evaluation of the ROM of the canine cervical spine allows the quantification of the maximum movement that the entire cervical spine could support, thus helping the surgeon to predict the postoperative result and determine the need for stabilization. Surprisingly, only a few biomechanical studies involving cervical laminectomy are available in the veterinary literature. CRISCO et al. (1990) did not report a significant increase in the ROM 6 months after performing dorsal laminectomy in dogs. In our study, in which destructive biomechanical testing was performed, dorsal laminectomy did not also improve the flexion and extension of the cervical spine in a single cycle under the conditions studied. When these results were compared with those of other cervical decompression techniques, it was observed that unilateral and bilateral facetectomies (BÖSCH et al., 2017) and ventral slot procedures reduced the stability of the functional vertebral unit. This is attributed to 
the fact that the intervertebral disc and articular facets play an important role in vertebral stabilization in flexion-extension and axial rotation (MACY et al., 1999; KOEHLER et al., 2005; ADAMO et al., 2007).

Finite element studies and in vitro biomechanical tests have shown that laminectomy causes great instability in the cervical columns compared with intact columns in humans (XIE et al., 2013; HEALY et al., 2016). Despite the lack of similar studies in dogs, possible biomechanical changes after performing Funkquist B laminectomy could assist in justifying why the condition of several patients worsen in the immediate postoperative period and in assessing the need for complementary stabilization. However, the results of our study do not support this hypothesis.

SMITH \& WALTER (1988) studied the biomechanics of the lumbar spine of dogs and reported an increase in the ROM and a decrease in the force applied to produce ventral flexion in $62 \%$ of the dogs when the interspinous ligament between the third and fourth lumbar vertebrae was removed. When laminectomy was performed in the same space, the ROM increased, and the force applied to produce ventral flexion reduced by $75 \%$. Regardless of methodological distinctions, the dorsal laminectomy performed in our study did not significantly increase the ROM, despite the removal of the interspinous ligament.

An in vitro biomechanical study on the canine lumbosacral spine showed that dorsal laminectomy alone had no significant effect on the stiffness of the lumbosacral movement unit (MEIJ et al., 2007). Despite the anatomical differences between the cervical region and the lumbosacral region, the preservation of the articular facets and intervertebral discs, with removal of only the spinous process, part of the blade, yellow ligament, and cervical interspinous ligaments, reinforces the hypothesis that these structures in the cervical region have a secondary effect in stabilizing flexion and extension. In our study, preserving the nuchal ligament and limiting the exaggerated movements of ventral flexion may have contributed to the absence of significant differences between the laminectomy and control groups.

SUBRAMANIAM et al. (2009) studied the mechanical effects of laminectomy on the human cervical spine and reported that laminectomy significantly increased the ROM during flexion and extension of the cervical spine compared with the cervical spine that did not undergo laminectomy. Moreover, laminectomy enlarged the spinal canal by
$101 \% \pm 4 \%$ and laminoplasty by $70 \% \pm 12 \%$. After laminectomy of human spinal columns applying mechanical flexion/extension forces, the ROM increased by $36 \%$ in the study by HEALY et al. (2016) and $21 \%$ in the study by KODE et al. (2012). XIE et al. (2013) reported that the ROM of human cervical spines in flexion/extension increased by $70 \%$ after $\mathrm{C} 3-\mathrm{C} 4$ laminectomy, 62\% after $\mathrm{C} 4-\mathrm{C} 5$ laminectomy, and $60 \%$ after $\mathrm{C} 5-\mathrm{C} 6$ laminectomy in a finite element study.

Based on these results, laminectomy can effectively decompress the spinal canal but somehow increases the ROM. These studies showed that there is usually an increase in the ROM after laminectomy in a specific cervical intervertebral space. In our study, we did not find an increase in the ROM in flexion/ extension, which could be explained by the fact that the laminectomy performed was less invasive (removal of $66 \%$ of each vertebral lamina) than the human cervical laminectomy shown in scientific studies, in which the entire lamina is normally removed. In our study, the nuchal ligament was preserved, maintaining the protective function, especially flexion; in our mechanical tests, the applied force mimicked the biomechanics and kinetics used when exercising a dog's head, which are closer to the results in actual settings that can be compared to those of other clinical studies. Although, these studies reported an increase in the ROM, the columns examined in our study were expected to show an increase in greater ROM (in $\mathrm{mm}$ ), denoting instability. However, this did not occur, which indicated the large difference between the human and canine species in terms of the decompression surgical technique. Our study showed that Funkquist B laminectomy performed between C6 and C7 in dogs does not generate instability and that there is a large difference between the human and canine species.

Some limitations of our study must be considered. Although, results allowed reliable interpretation, the limited number of samples per group yielded relatively high standard deviations and small differences. Additionally, the fixations of origin and insertion of the muscles were not maintained; however, the lack of musculature in vitro did not differ decisively from the in vivo results (BÜFF et al., 1990). Finally, the specimens underwent freezing and thawing, which could have altered their mechanical properties. However, cadaveric studies on pig and human spinal columns have shown that storage does not influence the mechanical properties of the samples (HONGO et al., 2008). Physical properties change only in the initial freezing cycle. Thus, it is 
hypothetically believed that the canine spine can follow the same characteristic.

Although, Funkquist B laminectomy decreased the mechanical resistance of the C6-C7 cervical segments compared with intact cervical models, it does not alter the ROM in flexion and extension. The spinous processes, partial dorsal lamina, interspinous ligament, and yellow ligament seemed to have a secondary role in cervical vertebral stabilization. Several studies have shown a progressive decrease in instability after surgery, suggesting that the biomechanical properties of the cervical spine may change over time (NG et al., 2003). Cervical spinal treatments that require Funkquist B laminectomy do not appear to require complementary vertebral surgical stabilization. Studies using other types of laminectomy and a greater number of laminectomy procedures should be performed to expand the knowledge on the biomechanical effects of this technique.

\section{CONCLUSION}

Funkquist B dorsal cervical laminectomy between $\mathrm{C} 6$ and $\mathrm{C} 7$ decreases mechanical resistance with a supraphysiological loading force but does not alter the ROM, suggesting that it can be used without additional mechanical stabilization in dogs.

\section{ACKNOWLEDGMENTS}

The authors would like to thank Conselho Nacional de Desenvolvimento Científico e Tecnológico $(\mathrm{CNPq})$ for providing financial support.

\section{BIOETHICS AND BIOSSECURITY COMMITTEE APPROVAL}

The study was approved by the Ethics Committee on the Use of Animals of the Universidade Estadual Paulista - Unesp (protocol: 008456/18).

\section{DECLARATION OF CONFLICT OF INTEREST}

The authors declare no conflict of interest.

\section{AUTHORS' CONTRIBUTIONS}

Julián Andrés Sanjuán Galíndez contributed to the conception of study, study design, data collection, data analysis, and interpretation. Bruno W. Minto, Paulo V. T. Marinho, and Luís GGG Dias contributed to the conception of the study, study design, data analysis, and interpretation. Adrielly Dissenha, Dayvid V. F. Lucena, and V. V. Dias contributed to the collection of study data. Bruno W. Minto, Paulo V. T. Marinho, and Luís GGG drafted and reviewed the submitted manuscript. Julián A. S. Galíndez and Bruno W. Minto drafted, revised, and approved the submitted manuscript.

\section{REFERENCES}

ADAMO, P. et al. In vitro biomechanical comparison of cervical disk arthroplasty, ventral slot procedure, and smooth pins with polymethylmethacrylate fixation at treated and adjacent canine cervical motion units. Veterinary Surgery, v. 36, n. 8, p.729-741, 2007. Available from: <https://doi.org/10.1111/ j.1532-950X.2007.00327.x>. Accessed: Aug. 24, 2020. doi: 10.1111/j.1532-950X.2007.00327.x.

BÖSCH, N. et al. Effect of facetectomy on the three-dimensional biomechanical properties of the fourth canine cervical functional spinal unit: a cadaveric study. Veterinary and Comparative Orthopaedics and Traumatology, v. 30, n. 6, p.430-437, 2017. Available from: <https://doi.org/10.3415/VCOT-17-03-0043>. Accessed: Aug. 24, 2020. doi: 10.3415/VCOT-17-03-0043.

BÜFF, H.U. et al. Functional stability of the canine cervical spine after injury. A three-month in vivo study. Spine, v. 15, n. 10, p.1040-1046, 1990. Available from: <https://doi. org/10.1097/00007632-199015100-00011>. Accessed: Aug. 24, 2020. doi: 10.1097/00007632-199015100-00011

CRISCO, J.J. et al. The injured canine cervical spine after six months of healing. An in vitro three-dimensional study. Spine, v. 15, n. 10, p.1047-1052, 1990. Available from: <https://doi. org/10.1097/00007632-199015100-00012>. Accessed: Aug. 24, 2020. doi: 10.1097/00007632-199015100-00012.

DA COSTA, R. et al. Outcome of medical and surgical treatment in dogs with cervical spondylomyelopathy: 104 cases (1988-2004). Journal of the American Veterinary Medical Association, v. 233 , n. 8 , p.1284-1290, 2008. Available from: $<$ https//doi. org/10.2460/javma.233.8.1284>. Accessed: Aug. 24, 2020. doi: 10.2460/javma.233.8.1284.

DE RISIO, L. et al. Dorsal laminectomy for caudal cervical spondylomyelopathy: postoperative recovery and longterm follow-up in 20 dogs. Veterinary Surgery, v. 31, n. 5, p.418-427, 2002. Available from: <https://doi.org/10.1053/ jvet.2002.34673 >. Accessed: Aug. 24, 2020. doi: 10.1053/ jvet.2002.34673.

FERNANDES, R. et al. Cervical vertebral malformations in 9 dogs: radiological findings, treatment options and outcomes. Irish Veterinary Journal. v. 72, p.72:2, 2019. Available from: $<$ https:// doi.org/10.1186/s13620-019-0141-9>. Accessed: Aug. 24, 2020. doi: 10.1186/s13620-019-0141-9.

FUJIOKA, T. et al. A novel patient-specific drill guide template for stabilization of thoracolumbar vertebrae of dogs: cadaveric study and clinical cases. Veterinary Surgery, v. 48, n. 3, p.336342, 2019. Available from: <https://doi.org/10.1111/vsu.13140>. Accessed: Aug. 10, 2020. doi: 10.1111/vsu.13140.

HEALY, A.T. et al. Biomechanics of open-door laminoplasty with and without preservation of posterior structures. Journal of Neurosurgery Spine, v. 24, n. 5, p.746-751, 2016. Available from: $<$ https://doi.org/10.3171/2015.7.SPINE15229>. Accessed: Aug. 24, 2020. doi: 10.3171/2015.7.SPINE15229. 
HONGO, M. et al. Effect of multiple freeze-thaw cycles on intervertebral dynamic motion characteristics in the porcine lumbar spine. Journal of Biomechanics, v. 41, n. 4, p.916-920, 2008. Available from: $<$ https://doi.org/10.1016/j.jbiomech.2007.11.003> Accessed: Aug. 24, 2020. doi: 10.1016/j.jbiomech.2007.11.003.

HWANG, Y. et al. Operative techniques and preliminary outcomes following percutaneous endoscopic thoracolumbar pediculectomy in dogs. Veterinary Surgery, v. 45, p.84-94, 2016. Available from: $<$ https://doi.org/10.1111/vsu.12569>. Accessed: Aug. 24, 2020. doi: $10.1111 /$ vsu. 12569 .

KODE, S. et al. Effect of multilevel open-door laminoplasty and laminectomy on flexibility of the cervical spine: an experimental investigation. Spine, v. 37, n. 19, p.E1165-E1170, 2012. Available from: <https://10.1097/BRS.0b013e31825e6251>. Accessed: Aug. 24, 2020. doi: 10.1097/BRS.0b013e31825e6251.

KOEHLER, C. et al. Effect of a ventral slot procedure and of smooth or positive-profile threaded pins with polymethylmethacrylate fixation on intervertebral biomechanics at treated and adjacent canine cervical vertebral motion units. American Journal of Veterinary Research, v. 66, n. 4, p.678-687, 2005. Available from: $<$ https://doi.org/10.2460/ajvr.2005.66.678>. Accessed: Aug. 24, 2020. doi: 10.2460/ajvr.2005.66.678.

KOSUKE, H. et al. Retrospective study of dorsal laminectomy for multiple cervical intervertebral disk disease in small dogs Japanese Journal of Veterinary Anesthesia \& Surgery, v.47, p.21-26, 2016. Available from: <https://doi.org/10.2327/ jjvas.47.2>. Accessed: Aug. 24, 2020. doi: 10.2327/jjvas.47.21.

KUBO, S. et al. Biomechanical evaluation of cervical doubledoor laminoplasty using hydroxyapatite spacer. Spine, v. 28, n. 3, p.227-234, 2003. Available from: <https://doi.org/10.1097/01. BRS.0000042246.09816.20>. Accessed: Aug. 24, 2020. doi: 10.1097/01.BRS.0000042246.09816.20.

LEE, S. et al. Postoperative non-pathological fever following posterior cervical fusion surgery: is laminoplasty a better preventive method than laminectomy? Journal of Korean Neurosurgical Society, v. 63, n. 4, p.487-494, 2020. Available from: <https:// doi.org/10.3340/jkns.2019.0191>. Accessed: Aug. 24, 2020. doi: $10.3340 / \mathrm{jkns} .2019 .0191$.

LEWCHALERMWONG, P. et al. Canine vertebral screw and rod fixation system: design and mechanical testing. Veterinary and Comparative Orthopaedics and Traumatology, v. 31, n. 2, p.95101, 2018. Available from: <https://doi.org/10.1111/vsu.13189>. Accessed: Aug. 24, 2020. doi: 10.3415/VCOT-17-03-0040.

MACY, N.B. et al. Effect of disk fenestration on sagittal kinematics of the canine C5-C6 intervertebral space. Veterinary Surgery, v. 28, n. 3, p.171-179, 1999. Available from: <https:// doi.org/10.1053/jvet.1999.0171>. Accessed: Aug. 24, 2020. doi: $10.1053 /$ jvet.1999.0171.

MEIJ, B.P. et al. Biomechanical flexion-extension forces in normal canine lumbosacral cadaver specimens before and after dorsal laminectomy-discectomy and pedicle screw-rod fixation. Veterinary Surgery, v. 36, n. 8, p.742-751, 2007. Available from: $<$ https://doi.org/10.1111/j.1532-950X.2007.00331.x>. Accessed: Aug. 24, 2020. doi: 10.1111/j.1532-950X.2007.00331.x.

MOISSONNIER, P. et al. Radiography and biomechanics of sixth and seventh cervical vertebrae segments after disc fenestration and after insertion of an intervertebral body spacer. A canine cadaveric study. Veterinary and Comparative Orthopaedics and Traumatology, v. 27, n. 1, p.54-61, 2014. Available from: $<$ https:// doi.org/10.3415/VCOT-11-11-0159>. Accessed: Aug. 24, 2020. doi: 10.3415/VCOT-11-11-0159.

NG, H. et al. Finite element analysis of cervical spinal instability under physiologic loading. Journal of Spinal Disorders \& Techniques, v. 16, n. 1, p.55-65, 2003. Available from: <https:// doi.org/10.1097/00024720-200302000-00010>. Accessed: Aug. 24, 2020. doi: 10.1097/00024720-200302000-00010.

SANTINI, G. et al. Cervical intervertebral disk disease in dogs: 28 cases (2003-2008). Pesquisa Veterinária Brasileira, v. 30, n. 8, p.659-664, 2010. Available from: <http://www.scielo.br/scielo. php?script $=$ sci_arttext\&pid=S0100736X2010000800009\&lng $=$ en $\& n r m=$ iso $>$. Accessed: Aug. 24, 2020. doi: 10.1590/S0100736 X2010000800009.

SHIMIZU, T. et al. Spontaneous anterior arch fracture of the atlas following $\mathrm{C} 1$ laminectomy without fusion: a report of three cases and finite element analysis. Journal of Orthopaedic Science, v. 21, n. 3, p.306-315, 2016. Available from: $<$ https://doi. org/10.1016/j.jos.2016.02.008>. Accessed: Aug. 24, 2020. doi: 10.1016/j.jos.2016.02.008.

SMITH, G.K.; WALTER, M.C. Spinal decompressive procedures and dorsal compartment injuries: comparative biomechanical study in canine cadavers. American Journal of Veterinary Research, v. 49, n. 2, p.266-273, 1988. Available from: <https://pubmed.ncbi. nlm.nih.gov/3348537/>. Accessed: Aug. 24, 2020.

SUBRAMANIAM, V. et al. Biomechanical effects of laminoplasty versus laminectomy: stenosis and stability. Spine, v. 34, n. 16, p.E573-E578, 2009. Available from: <https://doi.org/10.1097/ BRS.0b013e3181aa0214>. Accessed: Aug. 24, 2020. doi: 10.1097/ BRS.0b013e3181aa0214.

TAYLOR-BROWN, F.E. et al. Risk factors for early post-operative neurological deterioration in dogs undergoing a cervical dorsal laminectomy or hemilaminectomy: 100 cases (2002-2014). Veterinary Journal, v. 206, n. 3, p.327-331, 2015. Available from: $<$ https://doi.org/10.1016/j.tvj1.2015.10.010>. Accessed: Aug. 24, 2020. doi: 10.1016/j.tvjl.2015.10.010.

TUAN, J. et al. Ventral distraction-stabilization in 5 continuous sites for the treatment of cervical spondylomyelopathy in a Great Dane. Veterinary Surgery, v. 48, n. 4, p.607-614, 2019. Available from: <https://doi.org/10.1111/vsu.13189>. Accessed: Aug. 24, 2020. doi: $10.1111 /$ vsu. 13189 .

XIE, T. et al. Biomechanical comparison of laminectomy, hemilaminectomy and a new minimally invasive approach in the surgical treatment of multilevel cervical intradural tumour: a finite element analysis. European Spine Journal, v. 22, n. 12, p.27192730, 2013. Available from: <https://doi.org/10.1007/s00586-0132992-1. Epub 2013 Sep 7>. Accessed: Aug. 24, 2020. doi: 10.1007/ s00586-013-2992-1.

YOSHII, T. et al. Comparison of anterior decompression with fusion and posterior decompression with fusion for cervical spondylotic myelopathy-a systematic review and meta-analysis. Journal of Orthopaedic Science, S0949-2658(20)300014, 2020. Available from: <https://doi.org/10.1016/j. jos.2019.12.010>. Accessed: Aug. 24, 2020. doi: 10.1016/j. jos.2019.12.010. 